\title{
IF YOU WERE A MIGRANT. CANDIDATE PREFERENCE AS A HYPOTHESIS ${ }^{1}$
}

\section{SI USTED FUERA MIGRANTE. LAS PREFERENCIAS DE CANDIDATO COMO HIPÓTESIS}

\author{
Antonio Alaminos Chica \\ Universidad de Alicante (Spain) \\ alaminos@ua.es \\ Clemente Penalva Verdú \\ Universidad de Alicante (Spain) \\ clemente.penalva@ua.es \\ Ignacia Perea Crespo \\ OBETS - Universitat d'Alacant (Spain) \\ nachicrespo@gmail.com
}

\begin{abstract}
Based on data from a survey of all countries in the European Union (UE25), we attempt to comprehend the way in which European societies link concepts of citizenship (based on the possible transfer of voting rights in cases of geographic mobility) with their voting preferences (based on preference for a candidate from either their country of origin or the destination country) in the hypothetical case that survey respondents were to migrate to another country in

1 This study was financed by project CSO2012-32930, "La participación política como candidatos de los residentes europeos en España'"'Political participation as candidates by European residents living in Spain", by the Ministry of Economy and Competitiveness (Spain). These data are taken from the Flash Eurobarometer 364.
\end{abstract}


the European Union. The results show a significant correlation between four different notions of citizenship in cases of mobility (nation-based, state-based, cosmopolitan, and based on the forfeiture of voting rights) and the preferred candidate's country of origin. A nation-based view of citizenship is linked to a preference for candidates from the respondent's country of origin, while respondents with a state-oriented view of citizenship are likely to prefer candidates from their country of destination. The conclusions drawn from this exploratory study allow us to further reflect on the explanatory factors that influence these conceptions of nationality and citizenship (within the current context of economic and social crisis), as well as on the effect this set of public opinion may have on the future of the European Union as a supranational, democratic political project.

Key words: citizenship, nationality, intra-European mobility, European Union, public opinion

\section{INTRODUCTION}

This study centres on the voting preferences of European citizens within a context of interstate mobility, which is both recognised and promoted by the European Union. Given the intensity of mobility within the European area over the past few years, the makeup of political society in the various member states has changed. This has given way to the both actual and theoretical possibility of progressive plurinational political societies made up of European citizens who vote, create, and are candidates for new political organisations formed mostly at the local level by citizens residing in a country other than their country of origin. The most jarring new development for native voters is the emergence of new political parties established by foreign residents, as well as the realisation that the list of candidates belonging to "traditional" parties are now peppered with foreign-sounding names. Departing from the premise of attempting to understand this new political situation, the present study aims to assess the extent to which the voting preferences of European citizens are biased towards candidates from their own country of origin, or whether a candidate's nationality is irrelevant when choosing whom to vote for.

Although voting is not the only form of political participation, the present study is based on the idea that voting is one of the most substantial rights granted to the migrant population in any given country of destination. The ability to be both candidate and voter has uses that are both practical (providing a platform to promote one's own interests and/or ideologies) and symbolic (direct recognition of one's political rights and willingness to participate in the national political system). Though rare, there have been several studies on the migrant attitudes and political behaviour. What have not been researched are the voting preferences of potential or would-be emigrants who have not yet left 
their countries of origin; this focus is what sets the present study apart. It utilises questions from the 2012 Eurobarometer that ask the respondent to place themselves in a new social and political context in order to assess what their political preferences would be within that hypothetical situation. Of course, those who have not experienced international migration first-hand cannot know exactly what it is like. However, this thought experiment can provide some clues as to what respondents think about the limits of political and social rights granted to the migrant population in their countries. Additionally, it allows us to indirectly infer the correlation between voting preferences and concepts of citizenship in our current context, which is characterised by international mobility.

It is very challenging to study the political preferences and voting behaviour of migrants (particularly from a comparative point of view), not least because there exist very little data. There are several reasons behind these limitations, including the numerous countries of origin observed in migration flows, scattered areas of settlement, high rates of geographic mobility within destination countries, linguistic diversity, and social status, which is often quite low. All of these factors come together to produce such a high amount of heterogeneity that the very concept of migration itself encompasses a diverse range of socioeconomic topics.

Bird, Saalfeld y Wüst (2011) note the difficulty of obtaining comparative data in their study on the voting behaviour of immigrants.

The main conclusions are that suitable data are scarce and analyses are often quite idiosyncratic. Data source range from voter registers (Scandinavia), partially cumulated general surveys (eg. Canada. UK. Germany), to special minority-focused surveys (e g. France. Netherlands, Austria. UK). In none of the countries are data available for all political levels. While some countries focus largely or exclusively on local elections, others look almost exclusively at the national level. This difference in the scale of analysis is clearly linked to state-level variations in voter eligibility. The chapter also shows that there are hardly any common standards for identifying eligible voters with an immigrant or visible minority background (exceptions are Canada and the UK). Consequently, the conditions for comparative analyses across countries are modest.

In addition to the many different migrant populations and especially their very diverse political cultures of origin, there is also a wide range of different approaches used to analyse voting behaviour: socio-demographic characteristics (Columbia School); long-term attachments and the role of issues and candidates (Michigan School); and economic calculus and ideological proximity (Rational Choice). The present study uses a macro-level approach; as 
the state is our unit of analysis, individual demographic characteristics (e.g. gender, age, socioeconomic status, views on different political or ideological proposals) are condensed into broad categories.

Within the European case that this study focuses on, the legal framework for voter participation in local and European elections is subject to standardised regulations regarding the participation of migrants from other countries in the European Union. Thus, a European citizen who wishes to exercise their right to vote (whether passive or active) in local or European elections may do so in accordance with the registration conditions specified by each country. The explanatory power of the Political Opportunity Structure (Tarrow, 1998) is weakened when it comes to emigrants, at least insofar as legal feasibility. However, it does remain valid for other political, economic, and social aspects.

The main objective of this study is to assess the preference of voters who have hypothetically migrated to another country for either a candidate from their country of origin or country of residence. This involves a very interesting methodological approach. Given the high cost of studying the voting preferences of European migrants within their countries of residence, and given that the available data are sparse and of questionable credibility, the present study used a question posed to the general population that contained two hypothetical elements. A standard survey of the general population, Flash Eurobarometer, 364 (European Commission, Brussels, 2012) linked the following two considerations into one question: a) imagine that you have emigrated to a different country within the European Union, and b) imagine that in the European elections, you may vote either for candidates from your country of origin or from the European country in which you currently reside. Given these conditions, which candidate would you prefer: one from your country of origin, or one from your country of residence?

It can evidently be inferred, albeit with certain difficulties, that said preferences could be extrapolated to real-life cases of emigration. One difficulty is clearly the fact that actual emigrants often comprise part of a subpopulation that does not reflect the heterogeneity of the general population. However, one advantage is that using European elections helps to balance out the very particular nature of local elections, about which it is hardly realistic to form hypotheses regarding their candidates; European elections provide a point of cross-reference to help compare between different candidates.

In any case, it should be noted that the hypothetical assumption of migration lends the question projective characteristics that encourage a more open and sincere response. On the other hand, one disadvantage is that hypothetical questions are generally less likely to be answered (Alaminos, 1994), at least in populations or subpopulations with less of an ability to speculate.

Secondly, after posing the hypothetical migration scenario, candidate preferences are evaluated in terms of the respondent's conception of political rights in Europe. Thus, a recent article (Alaminos, Penalva y Perea, 2017) 
outlines a system for classifying voters by their opinion on the extent to which the active right to vote should be acquired or lost in national elections, examining the relation between these through the lens of civic-political cultural clusters within the European Union. The article also analyses dimensionality using two main axes: nation vs. state and forfeiture of rights vs. cosmopolitanism. The spectrum formed by these two dimensional axes results in four categories under which countries can be classified.

Table 1. Conception of citizenship based on the right to vote in general elections after migration

\begin{tabular}{|c|c|c|c|}
\hline & \multicolumn{2}{|c|}{ Active voting rights within country of residence } \\
\hline & & No & Yes \\
\hline \multirow{2}{*}{$\begin{array}{c}\text { Active voting rights } \\
\text { within country of origin }\end{array}$} & No & $\begin{array}{c}\text { Based on forfeiture of } \\
\text { rights }\end{array}$ & $\begin{array}{c}\text { Aristotelian citizenship } \\
\text { (State-based) }\end{array}$ \\
\hline & Yes & $\begin{array}{l}\text { Roman citizenship } \\
\text { (Nation-based) }\end{array}$ & $\begin{array}{l}\text { Cosmopolitan } \\
\text { citizenship }\end{array}$ \\
\hline
\end{tabular}

Source: Alaminos, Penalva, Perea (2017)

The proposed classifications enable an analysis on the percentage of individuals from each country who fall under each of the categories of understanding of the right to political participation via voting within the context of intra-European mobility. These four different conceptions of the right to vote derive from the $2 \times 2$ chart formed by the potential answers to two questions.

"Q2. - Suppose a European national is living in a member state other than their country of origin (that is, the country in which they hold citizenship):

(1) Should this citizen lose their right to vote in the national elections of the country in which they hold citizenship?

(2) Should this citizen have the right to vote and to run as a candidate in the national elections of the member state in which they reside?"

The resulting classification chart establishes the following four conceptions of citizenship:

A. Citizenship based on forfeiture of rights. No right to vote in either the country of origin or country of destination: the individual forfeits their right to vote upon migration. They lose their ability to vote when they leave their country of origin.

B. State-based citizenship. The citizen retains their right to vote in the country of origin and does not acquire the right to vote in the country of destination. The right to vote is tied to the country of origin. 
C. Nation-based citizenship. The immigrant citizen acquires the right to vote in the country to which they emigrate, but they lose the right to vote in their country of origin. The right to vote is tied to the receiving country.

D. A cosmopolitanist view of citizenship recognises the right to vote in general elections in both the country of origin and the receiving country. In short, the individual may choose which country to vote in, without exceptions.

The results obtained in each category for every country in the European Union are shown in Table 2.

Table 2. Conceptions of citizenship in each European country (2012)

\begin{tabular}{|l|r|r|r|r|r|r|}
\hline & $\begin{array}{r}\text { No } \\
\text { rights- } \\
\text { oriented }\end{array}$ & $\begin{array}{c}\text { Nation- } \\
\text { oriented }\end{array}$ & $\begin{array}{c}\text { State- } \\
\text { oriented }\end{array}$ & $\begin{array}{c}\text { Cosmopolitanist- } \\
\text { oriented }\end{array}$ & $\begin{array}{c}\text { Don't } \\
\text { know }\end{array}$ & Total \\
\hline Austria & $9,50 \%$ & $27,10 \%$ & $21,40 \%$ & $34,90 \%$ & $7,20 \%$ & $100 \%$ \\
\hline Belgium & $10,00 \%$ & $19,30 \%$ & $27,90 \%$ & $36,60 \%$ & $6,30 \%$ & $100 \%$ \\
\hline Bulgaria & $6,50 \%$ & $21,60 \%$ & $17,50 \%$ & $47,70 \%$ & $6,60 \%$ & $100 \%$ \\
\hline Cyprus (Republic) & $7,90 \%$ & $24,10 \%$ & $18,90 \%$ & $43,80 \%$ & $5,30 \%$ & $100 \%$ \\
\hline Czech Republic & $7,60 \%$ & $25,40 \%$ & $17,30 \%$ & $42,20 \%$ & $7,60 \%$ & $100 \%$ \\
\hline Germany & $5,80 \%$ & $20,40 \%$ & $24,40 \%$ & $43,10 \%$ & $6,40 \%$ & $100 \%$ \\
\hline Denmark & $8,20 \%$ & $38,20 \%$ & $22,50 \%$ & $24,60 \%$ & $6,50 \%$ & $100 \%$ \\
\hline Estonia & $8,90 \%$ & $25,10 \%$ & $12,60 \%$ & $34,70 \%$ & $18,70 \%$ & $100 \%$ \\
\hline Spain & $6,80 \%$ & $23,20 \%$ & $19,60 \%$ & $44,30 \%$ & $6,10 \%$ & $100 \%$ \\
\hline Finland & $7,70 \%$ & $29,40 \%$ & $13,30 \%$ & $41,50 \%$ & $8,10 \%$ & $100 \%$ \\
\hline France & $9,50 \%$ & $29,60 \%$ & $18,00 \%$ & $40,20 \%$ & $2,80 \%$ & $100 \%$ \\
\hline United Kingdom & $11,70 \%$ & $14,20 \%$ & $32,60 \%$ & $33,70 \%$ & $7,90 \%$ & $100 \%$ \\
\hline Greece & $6,10 \%$ & $21,30 \%$ & $17,80 \%$ & $48,30 \%$ & $6,40 \%$ & $100 \%$ \\
\hline Hungary & $7,60 \%$ & $32,00 \%$ & $14,10 \%$ & $38,50 \%$ & $7,90 \%$ & $100 \%$ \\
\hline Ireland & $6,40 \%$ & $9,40 \%$ & $31,70 \%$ & $47,70 \%$ & $4,90 \%$ & $100 \%$ \\
\hline Italy & $5,50 \%$ & $17,20 \%$ & $25,00 \%$ & $44,30 \%$ & $8,00 \%$ & $100 \%$ \\
\hline Lithuania & $9,60 \%$ & $31,50 \%$ & $15,90 \%$ & $34,40 \%$ & $8,60 \%$ & $100 \%$ \\
\hline Luxembourg & $9,30 \%$ & $17,80 \%$ & $27,30 \%$ & $41,50 \%$ & $4,20 \%$ & $100 \%$ \\
\hline Latvia & $11,80 \%$ & $30,40 \%$ & $15,90 \%$ & $33,90 \%$ & $8,10 \%$ & $100 \%$ \\
\hline Malta & $7,70 \%$ & $18,10 \%$ & $29,30 \%$ & $37,70 \%$ & $7,30 \%$ & $100 \%$ \\
\hline The Netherlands & $10,30 \%$ & $25,10 \%$ & $23,00 \%$ & $35,90 \%$ & $5,80 \%$ & $100 \%$ \\
\hline Poland & $6,50 \%$ & $21,60 \%$ & $18,10 \%$ & $50,20 \%$ & $3,60 \%$ & $100 \%$ \\
\hline Portugal & $4,70 \%$ & $19,00 \%$ & $18,20 \%$ & $55,50 \%$ & $2,60 \%$ & $100 \%$ \\
\hline Romania & $6,90 \%$ & $13,90 \%$ & $21,70 \%$ & $52,20 \%$ & $5,30 \%$ & $100 \%$ \\
\hline Sweden & $6,00 \%$ & $34,00 \%$ & $13,10 \%$ & $40,60 \%$ & $6,20 \%$ & $100 \%$ \\
\hline Slovenia & $12,00 \%$ & $22,40 \%$ & $25,60 \%$ & $33,70 \%$ & $6,30 \%$ & $100 \%$ \\
\hline Slovakia & Pen $\%$ & $17,50 \%$ & $42,50 \%$ & $7,90 \%$ & $100 \%$ \\
\hline & & & & & & \\
\hline
\end{tabular}

Source: Alaminos, Penalva, Perea (2017) on the data of Flashbarometer 364 (European Commission, Brussels, 2012) 
If you were a migrant. Candidate preference as a hypothesis

\section{DATA AND HYPOTHESIS}

The data used to test our hypothesis come from the survey of public opinion conducted on behalf of the European Commission -Flash Eurobarometer 364,(European Commission, Brussels, 2012). The question posed attempts to have the survey respondent imagine they are a resident in a European country different to their own. It asks how they would feel about voting a) for candidates from their own country (both the active and passive right to vote are understood to apply to the same nationality of origin) or b) for candidates with a differing active right to vote (foreign resident) and passive right to vote (a candidate from the country of destination). This is how the question is posed in the survey:

Q3. If you are living or were to live in an EU country other than your country of origin (i.e. the country in which you are a national), would you rather vote in European elections for "the candidates of your country of residence or the candidates of your country of origin"?

Table 3 shows the results of this question for each country. It should be noted, however, that hypothetical questions are generally less likely to be answered (Alaminos, 1994). The percentage of unanswered questions is especially high in the case of Austria, Germany, and Estonia, at around 20-25\%.

The data analysis consists of comparing the responses to this question about voting preferences with the four classifications detailed above (a product of the operationalisation of two questions) used to categorise different views on the right to vote in cases of intra-European mobility. All of the questions have only two possible answers. All cases asked the respondents to place themselves in a hypothetical situation. Thus, in order to ask about the potential acquisition or loss of the right to vote (the answers to which have been used to categorise the different understandings of citizenship), the following two questions were posed: "Suppose a citizen of one European country lives in a different country in the European Union" (a. Should they retain the right to vote in their country of origin? and $b$. Should they acquire the right to vote in the country of destination?). The same approach was used to ask about candidate preferences. The possible answers to the question about acquiring and/or retaining the right to vote in national elections were "yes" or "no"; in the question regarding candidate preferences, the options were between voting for candidates from the respondent's country of origin or candidates from their country of residence. 
Table 3. Candidate preferences according to country of origin for each EU country

\begin{tabular}{|l|c|c|c|c|}
\hline & $\begin{array}{c}\text { The } \\
\text { candidates of } \\
\text { your country } \\
\text { of residence }\end{array}$ & $\begin{array}{c}\text { The } \\
\text { candidates } \\
\text { of your } \\
\text { country of } \\
\text { origin }\end{array}$ & $\begin{array}{c}\text { Don't } \\
\text { know }\end{array}$ & Total \\
\hline Austria & $42,60 \%$ & $32,50 \%$ & $24,90 \%$ & $100 \%$ \\
\hline Belgium & $53,00 \%$ & $37,20 \%$ & $9,80 \%$ & $100 \%$ \\
\hline Bulgaria & $33,20 \%$ & $60,60 \%$ & $6,20 \%$ & $100 \%$ \\
\hline Cyprus (Republic) & $39,10 \%$ & $54,90 \%$ & $5,90 \%$ & $100 \%$ \\
\hline Czech Republic & $48,60 \%$ & $39,80 \%$ & $11,70 \%$ & $100 \%$ \\
\hline Germany & $49,20 \%$ & $28,70 \%$ & $22,00 \%$ & $100 \%$ \\
\hline Denmark & $36,20 \%$ & $52,10 \%$ & $11,70 \%$ & $100 \%$ \\
\hline Estonia & $31,50 \%$ & $48,80 \%$ & $19,70 \%$ & $100 \%$ \\
\hline Spain & $56,40 \%$ & $38,30 \%$ & $5,30 \%$ & $100 \%$ \\
\hline Finland & $36,70 \%$ & $57,90 \%$ & $5,40 \%$ & $100 \%$ \\
\hline France & $47,30 \%$ & $47,40 \%$ & $5,30 \%$ & $100 \%$ \\
\hline United Kingdom & $54,80 \%$ & $38,60 \%$ & $6,60 \%$ & $100 \%$ \\
\hline Greece & $47,20 \%$ & $47,90 \%$ & $4,90 \%$ & $100 \%$ \\
\hline Hungary & $52,10 \%$ & $39,00 \%$ & $8,80 \%$ & $100 \%$ \\
\hline Ireland & $54,40 \%$ & $39,90 \%$ & $5,70 \%$ & $100 \%$ \\
\hline Italy & $57,60 \%$ & $34,50 \%$ & $7,90 \%$ & $100 \%$ \\
\hline Lithuania & $25,30 \%$ & $64,80 \%$ & $9,90 \%$ & $100 \%$ \\
\hline Luxembourg & $51,90 \%$ & $40,00 \%$ & $8,10 \%$ & $100 \%$ \\
\hline Latvia & $36,10 \%$ & $52,50 \%$ & $11,40 \%$ & $100 \%$ \\
\hline Malta & $51,50 \%$ & $42,60 \%$ & $5,90 \%$ & $100 \%$ \\
\hline The Netherlands & $46,70 \%$ & $41,30 \%$ & $12,00 \%$ & $100 \%$ \\
\hline Poland & $35,00 \%$ & $55,00 \%$ & $10,00 \%$ & $100 \%$ \\
\hline Portugal & $39,30 \%$ & $57,40 \%$ & $3,30 \%$ & $100 \%$ \\
\hline Romania & $28,80 \%$ & $66,10 \%$ & $5,10 \%$ & $100 \%$ \\
\hline Sweden & $42,70 \%$ & $48,00 \%$ & $10,20 \%$ & $100 \%$ \\
\hline Slovenia & $44,50 \%$ & $47,90 \%$ & $7,60 \%$ & $100 \%$ \\
\hline Slovakia & & & & \\
\hline & & $48,50 \%$ & $9,50 \%$ & $100 \%$ \\
\hline
\end{tabular}

Source: Prepared by the authors on the basis of Flash Eurobarometer 364 data (European Commission, Brussels, 2012)

The main hypothesis of the present study is that public opinion of the different conceptions of citizenship (in terms of the right to vote in cases of mobility) are linked to a preference in European elections for a certain type of candidate, as determined by their country of origin (whether a compatriot or from the receiving country). From this, the following hypotheses are formed: 
- An understanding of citizenship as nation-based (the right to vote should not be granted in the country of destination) is positively correlated with a preference for candidates from the respondent's country of origin. If a person thinks that immigrants should only retain the right to vote in their country of origin, even if they themselves were to immigrate to a different country (where, despite their opinion, they would in fact have the right to vote), they would vote for their compatriots. This relation points to a kind of nationalistic sentiment that moves one to view citizenship as being firmly rooted in the country of origin rather than influenced by living in a political community different to that of one's own country. This sentiment also moves one to appreciate or have a positive view of candidates from their country of origin.

- There is a negative correlation between a nation-based understanding of citizenship and a preference for candidates from the receiving country. This correlation is the opposite of the one outlined in the previous hypothesis.

- There is a positive correlation between a state-based understanding of citizenship and a preference for candidates from the receiving country. This view holds that citizenship and the right to vote should be determined by an immigrant's country of residence, to the extent that they lose political ties to their country of origin. In terms of political identity, an individual's preference for candidates from the receiving country is consistent with a state-based understanding of citizenship; it shows a predisposition to assimilate and assume a new citizenship.

- There is a positive correlation between a cosmopolitan understanding of citizenship and a preference for candidates from the receiving country. These attitudes will be very similar to those of the state-based understanding of citizenship. Although the individual does not lose the right to vote in their country of origin, they consider it more important to integrate into their new context (voting for candidates from the receiving country) than to act on nationalistic sentiment (by voting for candidates from their country of origin). 


\section{Graph 1. Graphical representation of the hypothesis}

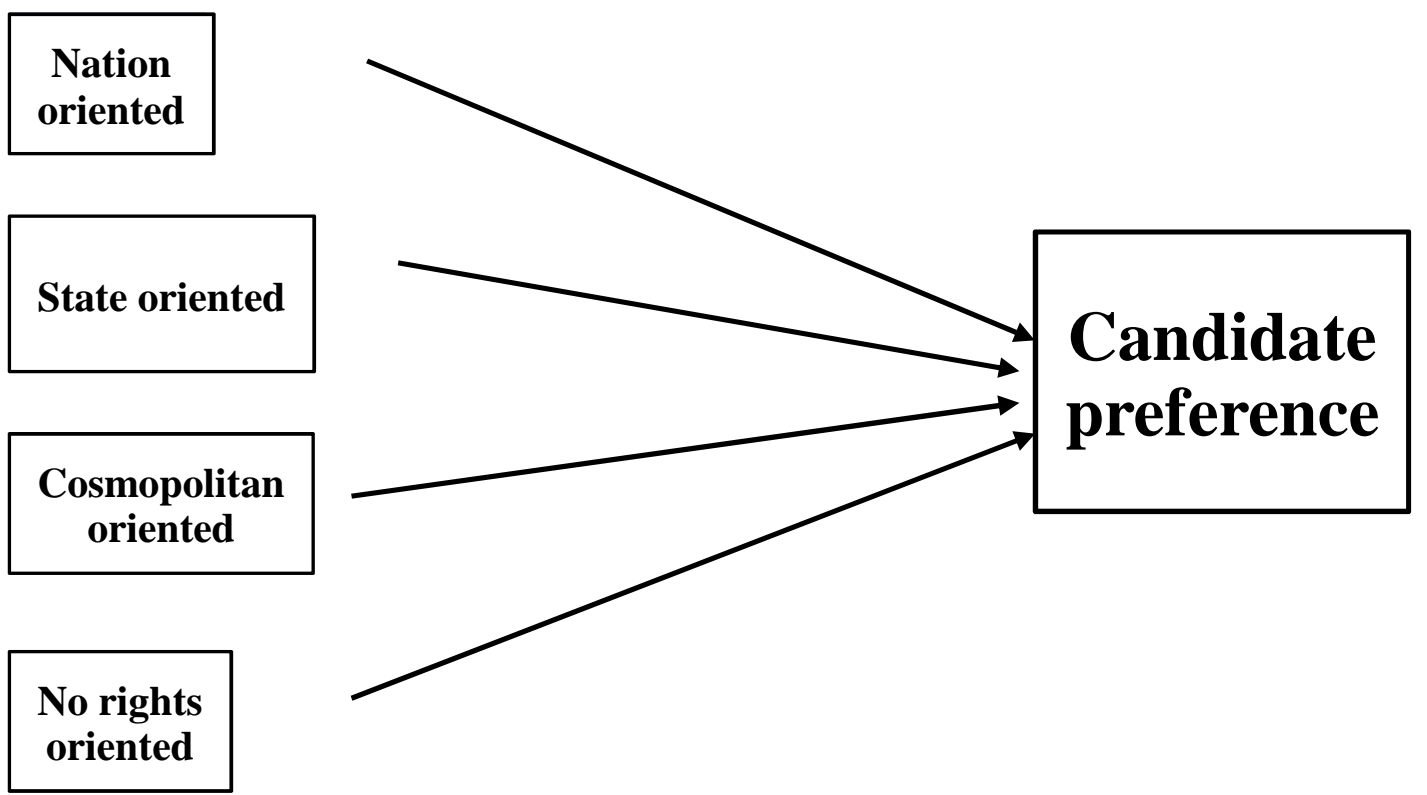

\section{RESULTS}

Table 4 shows the results of the hypothesis test carried out by comparing the two variables (conception of citizenship and candidate preference). Despite a relatively high percentage of questions left unanswered, the different directions of the coefficients for each of the considered countries enables us to confirm these correlations. A considerable amount of boxes with significant correlations enable the confirmation of the aforementioned hypotheses.

Table 4. Candidate nationality preferences according to views on the right to vote in 2012

\begin{tabular}{|l|l|c|c|c|c|}
\hline $\begin{array}{l}\text { Preference for candidate of the country of } \\
\text { destination (1) or origin (0) }\end{array}$ & $\begin{array}{c}\text { Nation } \\
\text { oriented }\end{array}$ & $\begin{array}{c}\text { State } \\
\text { oriented }\end{array}$ & $\begin{array}{c}\text { Cosmopolitan } \\
\text { oriented }\end{array}$ & $\begin{array}{c}\text { No rights } \\
\text { oriented }\end{array}$ \\
\hline \multirow{4}{*}{ Austria } & Pearson's Correlation &,$- 192^{* *}$ &, $177^{* *}$ &, 028 &,- 010 \\
\cline { 2 - 6 } & Sig. (unilateral) &, 000 &, 000 &, 220 &, 392 \\
\cline { 2 - 6 } & $\mathrm{N}$ & 753 & 753 & 753 & 753 \\
\hline \multirow{4}{*}{ Belgium } & Pearson's Correlation &,$- 141^{* *}$ &, 009 &, $139^{* *}$ &,$- 056^{*}$ \\
\cline { 2 - 6 } & Sig. (unilateral) &, 000 &, 397 &, 000 &, 048 \\
\cline { 2 - 6 } & $\mathrm{N}$ & 903 & 903 & 903 & 903 \\
\hline \multirow{4}{*}{ Bulgaria } & Pearson's Correlation &,$- 150^{* * *}$ &, $228^{* *}$ &,- 030 &, 027 \\
\cline { 2 - 6 } & Sig. (unilateral) &, 000 &, 000 &, 178 &, 207 \\
\cline { 2 - 6 } & $\mathrm{N}$ & 947 & 947 & 947 & 947 \\
\hline \multirow{5}{*}{ Cyprus (Republic) } & Pearson's Correlation &,$- 244^{* * *}$ &, $111^{* *}$ &, $128^{* *}$ &,- 029 \\
\cline { 2 - 6 } & Sig. (unilateral) &, 000 &, 008 &, 003 &, 263 \\
\cline { 2 - 6 } & $\mathrm{N}$ & 476 & 476 & 476 & 476 \\
\hline \multirow{3}{*}{ Czech Republic } & Pearson's Correlation &,$- 125^{* * *}$ &, 001 &, $128^{* *}$ &,- 048 \\
\cline { 2 - 6 } & Sig. (unilateral) &, 000 &, 491 &, 000 &, 079 \\
\cline { 2 - 6 } & $\mathrm{N}$ & 883 & 883 & 883 & 883 \\
\hline
\end{tabular}


If you were a migrant. Candidate preference as a hypothesis

\begin{tabular}{|c|c|c|c|c|c|}
\hline \multirow[t]{3}{*}{ Germany } & Pearson's Correlation &,$- 204^{* *}$ & , $105^{* *}$ &, $075^{*}$ &,- 034 \\
\hline & Sig. (unilateral) & ,000 & ,002 & ,019 & ,169 \\
\hline & $\mathrm{N}$ & 780 & 780 & 780 & 780 \\
\hline \multirow[t]{3}{*}{ Denmark } & Pearson's Correlation &,$- 288^{* *}$ & $316^{* *}$ &, $077^{*}$ &,$- 060^{*}$ \\
\hline & Sig. (unilateral) & ,000 &, 000 &, 011 & ,036 \\
\hline & $\mathrm{N}$ & 891 & 891 & 891 & 891 \\
\hline \multirow[t]{3}{*}{ Estonia } & Pearson's Correlation &,$- 201^{* *}$ &, $096^{* *}$ & $101^{* *}$ & ,035 \\
\hline & Sig. (unilateral) & ,000 &, 003 &, 002 & 161 \\
\hline & $\mathrm{N}$ & 805 & 805 & 805 & 805 \\
\hline \multirow[t]{3}{*}{ Spain } & Pearson's Correlation &,$- 189^{* *}$ & , $112^{* *}$ & $103^{* *}$ &,- 017 \\
\hline & Sig. (unilateral) & 000 &, 000 & ,001 & 303 \\
\hline & $\mathrm{N}$ & 947 & 947 & 947 & 947 \\
\hline \multirow[t]{3}{*}{ Finland } & Pearson's Correlation &,$- 265^{* *}$ & $156^{* *}$ & $142^{* *}$ & ,045 \\
\hline & Sig. (unilateral) & ,000 &, 000 &, 000 & ,082 \\
\hline & $\mathrm{N}$ & 947 & 947 & 947 & 947 \\
\hline \multirow[t]{3}{*}{ France } & Pearson's Correlation &,$- 262^{* *}$ &, $202^{* *}$ &, $134^{* *}$ &,$- 072^{*}$ \\
\hline & Sig. (unilateral) &, 000 &, 000 &, 000 & ,013 \\
\hline & $\mathrm{N}$ & 949 & 949 & 949 & 949 \\
\hline \multirow[t]{3}{*}{ United Kingdom } & Pearson's Correlation &,$- 163^{* *}$ &, $114^{* *}$ &, $062^{*}$ &,$- 082^{* * *}$ \\
\hline & Sig. (unilateral) &, 000 &, 000 &, 028 & ,006 \\
\hline & $\mathrm{N}$ & 935 & 935 & 935 & 935 \\
\hline \multirow[t]{3}{*}{ Greece } & Pearson's Correlation &,$- 167^{* *}$ &, $058^{*}$ &, $164^{* *}$ &,$- 082^{* *}$ \\
\hline & Sig. (unilateral) &, 000 &, 036 &, 000 & ,006 \\
\hline & $\mathrm{N}$ & 951 & 951 & 951 & 951 \\
\hline \multirow[t]{3}{*}{ Hungary } & Pearson's Correlation &,$- 126^{* *}$ & $144^{* *}$ &,- 048 &, $125^{* *}$ \\
\hline & Sig. (unilateral) & ,000 &, 000 &, 073 & ,000 \\
\hline & $\mathrm{N}$ & 918 & 918 & 918 & 918 \\
\hline \multirow[t]{3}{*}{ Ireland } & Pearson's Correlation &,$- 119^{* *}$ & , $134^{* *}$ &,- 011 &,$- 089^{* *}$ \\
\hline & Sig. (unilateral) & ,000 &, 000 &, 371 & ,003 \\
\hline & $\mathrm{N}$ & 943 & 943 & 943 & 943 \\
\hline \multirow[t]{3}{*}{ Italy } & Pearson's Correlation &,$- 208^{* * *}$ & , $111^{* *}$ & ,119** &,$- 063^{*}$ \\
\hline & Sig. (unilateral) &, 000 &, 000 &, 000 & ,027 \\
\hline & $\mathrm{N}$ & 921 & 921 & 921 & 921 \\
\hline \multirow[t]{3}{*}{ Lithuania } & Pearson's Correlation &,$- 149^{* *}$ &, $147^{* *}$ & ,041 & ,034 \\
\hline & Sig. (unilateral) &, 000 &, 000 & ,107 & 153 \\
\hline & $\mathrm{N}$ & 901 & 901 & 901 & 901 \\
\hline \multirow[t]{3}{*}{ Luxembourg } & Pearson's Correlation &,$- 099^{*}$ &, $151^{* *}$ & ,008 &,$- 172^{* * *}$ \\
\hline & Sig. (unilateral) &, 017 & ,001 & ,429 & ,000 \\
\hline & $\mathrm{N}$ & 464 & 464 & 464 & 464 \\
\hline \multirow[t]{3}{*}{ Latvia } & Pearson's Correlation &,$- 142^{* * *}$ & $134^{* *}$ & ,002 &, $076^{*}$ \\
\hline & Sig. (unilateral) &, 000 &, 000 & ,475 & ,012 \\
\hline & $\mathrm{N}$ & 887 & 887 & 887 & 887 \\
\hline \multirow[t]{3}{*}{ Malta } & Pearson's Correlation &,$- 246^{* *}$ & $240^{* *}$ & ,002 &,- 029 \\
\hline & Sig. (unilateral) & ,000 & , 000 & ,483 & ,265 \\
\hline & $\mathrm{N}$ & 479 & 479 & 479 & 479 \\
\hline \multirow[t]{3}{*}{ The Netherlands } & Pearson's Correlation &,$- 153^{* *}$ &, $088^{* *}$ &, $081^{* *}$ &,$- 103^{* * *}$ \\
\hline & Sig. (unilateral) & ,000 & ,004 & ,008 & ,001 \\
\hline & $\mathrm{N}$ & 883 & 883 & 883 & 883 \\
\hline \multirow[t]{2}{*}{ Poland } & Pearson's Correlation &,$- 085^{* *}$ & $186^{* *}$ &,$- 060^{*}$ & ,000 \\
\hline & Sig. (unilateral) & ,005 & , 000 & ,035 & ,494 \\
\hline
\end{tabular}




\begin{tabular}{|l|l|c|c|c|c|}
\hline \multirow{4}{*}{ Portugal } & $\mathrm{N}$ & 900 & 900 & 900 & 900 \\
\cline { 2 - 5 } & Pearson's Correlation &,$- 142^{* *}$ &, $136^{* *}$ &, 021 &,- 012 \\
\cline { 2 - 5 } & Sig. (unilateral) &, 000 &, 000 &, 253 &, 353 \\
\cline { 2 - 5 } & $\mathrm{N}$ & 967 & 967 & 967 & 967 \\
\hline \multirow{5}{*}{ Romania } & Pearson's Correlation &,- 007 &, 001 &,- 044 &, $075^{*}$ \\
\cline { 2 - 6 } & Sig. (unilateral) &, 410 &, 490 &, 086 &, 010 \\
\cline { 2 - 6 } & $\mathrm{N}$ & 956 & 956 & 956 & 956 \\
\hline \multirow{5}{*}{ Slovenia } & Pearson's Correlation &,$- 301^{* *}$ &, $183^{* *}$ &, $180^{* *}$ &,- 036 \\
\cline { 2 - 6 } & Sig. (unilateral) &, 000 &, 000 &, 000 &, 143 \\
\cline { 2 - 6 } & $\mathrm{N}$ & 898 & 898 & 898 & 898 \\
\hline \multirow{5}{*}{ Slovakia } & Pearson's Correlation &,$- 191^{* *}$ &, $211^{* *}$ &, 049 &,- 017 \\
\cline { 2 - 6 } & Sig. (unilateral) &, 000 &, 000 &, 071 &, 303 \\
\cline { 2 - 6 } & $\mathrm{N}$ & 906 & 906 & 906 & 906 \\
\cline { 2 - 6 } & Pearson's Correlation &,- 022 &, $056^{*}$ &,- 025 &,- 028 \\
\cline { 2 - 6 } & Sig. (unilateral) &, 250 &, 045 &, 220 &, 202 \\
\cline { 2 - 5 } & $\mathrm{N}$ & 924 & 924 & 924 & 924 \\
\hline
\end{tabular}

**. Significant correlation at level 0,01 (unilateral).

*. Significant correlation at level 0,05 (unilateral).

Source: prepared by the authors on the basis of Flash Eurobarometer 364 data (European

Commission, Brussels, 2012)

Upon analysing the relationship between a preference for candidates from either the country of origin or receiving country with the classifications of citizenship, consistent, transnational attitudes are observed. A vertical view of the table reveals that relationships proposed in our hypotheses hold true for all of the countries, showing a) a correlation between a nation-based understanding of citizenship and a preference for forfeiture of citizenship upon emigration. Both are negatively correlated with a preference for candidates from the receiving country (negative in columns 1 and 4); and, similarly, b) there is a clear positive correlation between state-based views of citizenship and a belief in the right to citizenship in both countries after emigration. Both of these are associated (positive correlation in columns 2 and 3) with a preference for candidates from the receiving country.

This increase in preference for candidates from one's country of origin most likely reflects an increasingly nation-based understanding of citizenship over the past few years. Thus, in accordance with the four categories outlined above, there is a clear correlation between nation-based views of citizenship and a preference for candidates from one's country of origin. This relationship is reinforced by the positive correlation $(+)$ seen between citizenship based on forfeiture of rights and a preference for candidates from one's home country.

On the other hand, a horizontal analysis of the table reveals the sheer diversity of public opinion between countries. There are significant correlations in all four columns for countries like the Netherlands, Denmark, Greece, France, Italy, and the United Kingdom. These are all countries currently undergoing a noticeable growth in nationalist populism with the rise of authoritarian and 
xenophobic parties in the Netherlands (Partij voor de Vrijheid, PVV), Denmark (DanskFolkeparti), Greece (Amanecer Dorado/Golden Dawn), France (Front National), the United Kingdom (United Kingdom Independence Party, UKIP), and Italy (Lega Nord). To a lesser degree (with three significant coefficients), there is a large group of countries with very heterogeneous results: Belgium, Cyprus, Germany, Estonia, Finland, the Netherlands, Ireland, Luxembourg, Latvia, Poland, Spain, and Sweden. Finally, there is a group with two significant coefficients, comprised of most of the Eastern European countries, which have particular political, cultural, and societal characteristics due to historical communist regimes: Austria, Bulgaria, the Czech Republic, Lithuania, Malta, Portugal, and Slovenia; Slovakia and Romania both have only one strong coefficient.

\section{DISCUSSION AND CONCLUSIONS}

This is a transnational study of public opinion in European political societies regarding voting preferences for candidates within a context of interculturality, as well as of conceptions of citizenship (measured using respondents' opinions of whether the right to vote should be maintained or lost upon emigration from a country). The results allow us to explore the different societies' perceptions of the link between citizenship and nationality, within a context of growing intraEuropean mobility. One of the key findings of this study is that a preference for candidates from one's country of origin more than likely reflects the recent growing trend of nationalist sentiments in Europe. An analysis of the results reveals different groups of countries, which have been classified according to the level of consistency between their concepts of citizenship and their preferences for candidates from either their country of origin or country of residence. This grouping allows for the formation of new hypotheses, as well as reflection on the role of different structural or institutionalised factors (political culture, history, social structure, and legal/institutional heritage) and other relevant factors (especially economic factors, although international relations also come into play here). We can also examine other opinions (such as attitudes towards the European Union) that come into play when assessing the relationships between public opinion on these issues with a general population's conception of citizenship. Larger-scale future research (using new measures, a larger sample size, and over a longer period of time) will allow researchers to make predictions about the not-too-distant future of the European Union, a future shaped by the consequences of Europe's current situation. The idea of Europe as a political and intercultural entity is currently in crisis, and there is a lack of shared European immigration policy.

Supranational political projects like the European Union entail slight changes in the definition of sovereignty as a source of legitimate authority within any given state, and the definition of citizenship as a legal framework shared by 
those who make up a political community. On the one hand, member states forfeit part of their sovereignty to higher authorities like the Union, and channels for political participation are established within a new reality characterised by the free movement of people. On the other hand, the concept of citizenship also becomes more nuanced in order to include those who change their country of residence as a result of intra-European mobility. This is why the right to vote has been expanded in certain electoral processes (local and European elections), allowing all citizens of the EU to participate politically (whether as voters or as candidates) in their countries of residence, even if different from their country of origin.

Thus, this is an institutional project that was largely supported by the general public opinion of European societies. Within the context of economic development and socio-political stability, European societies have participated in and openly accepted an increasingly large Union (incorporating a number of countries from Eastern Europe) and subsequently an extension of voting rights. However, in recent years Europe has undergone an economic and social crisis that has altered national political climates and severely impacted the European Union itself as a political project. The data on public opinion presented here show what could be a symptom of evolving public sentiment on how to identify politically with Europe. Nationalist sentiments are beginning to rise up against the supranationalism that has resulted from growing cultural and economic globalisation in an international world. These growing nationalist sentiments are not limited to the European space, and they promote policies of national sovereignty (and the rejection of foreign imposition) based on nationalist ideologies. There have also been many economic political proposals aimed at safeguarding national economies. Within public policy, there has been a trend toward restricting social services and benefits provided to nonnationals. While this study centres on intra-European mobility, also relevant is the increasingly urgent humanitarian migrant crisis caused by armed conflicts linked to the European Union. This is a controversial topic that historically (in Europe) has not usually been linked to a growth in nationalism, provided that there are no on-going economic or social crises.

On the other hand, if public opinion on whom should be given the right to vote in a particular country provides us with clues on social and cultural concepts of citizenship and nationality, it is also worth remembering that this right is only one method of conventional political participation. The evolution of this political right has been one of the main transformative elements behind changing Western political systems throughout the modern era; these rights have progressively grown in accordance with increasingly open political systems that have become more inclusive of people living within the territory of a given state. The concepts of representation and sovereignty are linked both legally and ideologically to the promotion of individual rights within political societies. Thus, the right to vote has gradually been extended to more 
individuals, from a rejection of absolutist voting policies to the immigrant right to vote (transnational citizenship), moving from census suffrage to possible future concepts of universal suffrage, the latter a result of widely championed democratic principles of equality. This refers to a legal equality that has been promoted by European (or pro-European) political cultures, which have sought to secure equal opportunities and social equality by monitoring inequalities and preventing them from worsening.

Regarding the European project, the current nationalistic centrifugal forces (detected by this study in the public opinion of European societies) are linked to processes of internal centralisation and the loss of civil and social rights, as well as the denial of rights to minorities. In this sense, decisions made by the European Union should constitute a centripetal counterforce to these authoritarian movements and their ideological foundations. In other words, there should be an even stronger push for democracy. If European institutions have been lacking in democracy since their inception - a deficit that has its roots in the notable imbalance between economic and social policies - action should be taken in the current context to change economic policies of austerity for more expansive and inclusive ones. Such policies would strive for an increase in public spending on social services in order to stymie social polarisation, and they would factor prominently in changing public opinions of the different member states of the European Union.

\section{REFERENCES}

Alaminos, A. (1996). Teoría y práctica de la encuesta. Madrid: CEDEAL.

Alaminos, A. (2002). “Maneras de vivir la sociedad”. En: José Félix Tezanos (ed.), Europa en Clase, Status y poder en las sociedades emergentes. Madrid: Editorial Sistema.

Alaminos, A., Penalva, C., Perea, N. (2017), La opinión pública europea y el derecho al voto de los migrantes, Sistema (en revisión)

Alter, P. (1994). Nationalism. London: Edward Arnold.

Arce Jiménez, C. (2012). Los derechos políticos de los residentes extranjeros: la ciudadanía inclusiva. Sevilla: Defensor del Pueblo Andaluz.

Basch, L., Glick Schiller N., y Szanton-Blanc, C. (1994). Nations Unbound: Transnational Projects, Postcolonial Predicaments and Deterritorialized NationState. Amsterdam: Gordon \& Breach.

Bird, K., Saalfeld T. and Wüst, A.M. (2011). “The political representation of inmigrants and minorities. Voters, parties and parliaments in liberal democracies". London: Routledge.

Boli, J. y Thomas, G.M. (1999). "Chapter one INGOs and the Organization of World Culture", Constructing world culture: International nongovernmental organizations since 1875, , Stanford, Calif: Stanford University Press. 
Brown, G. W. y Held, D. (2010). The cosmopolitanism reader. Cambridge: Polity Press.

Castles, S. (2003). “Jerarquías de ciudadanía en el marco del orden global”. Anales de la Cátedra Francisco Suárez, 37 (Ciudadanía e inmigración).

Estévez, A. (2016). “¿Derechos humanos o ciudadanía universal? Aproximación al debate de derechos en la migración". Revista Mexicana de Sociología, vol. 78 , no. 1 .

European Commission, Brussels (2014): Flash Eurobarometer 364 (Electoral Rights). TNS Political \& Social [producer]. GESIS Data Archive, Cologne. ZA5883 Data file Version 1.0.0, doi:10.4232/1.11931

Glick Schiller, N. y Fouron, G.E. (1999). “Terrains of Blood and Nation: Haitian Transnational Social Fields".Ethnic and Racial Studies, vol. 22, no. 2.

Glick Schiller, N., Basch, L. y Szanton-Blanc, C. (1992). "Towards a Definition of Transnationalism. Introductory Remarks and Research Questions". En: Glick Schiller, N., Basch, L. y Szanton-Blanc, C. (Eds.), Towards a Transnational Perspective on Migration: Race, Class, Ethnicity and Nationalism Reconsidered.New York: New York Academy of Sciences. Guarnizo, L.E., Portes, A. y Haller, W. (2003). “Assimilation and Transnationalism: Determinants of Transnational Political Action among Contemporary Migrants". American Journal of Sociology, vol. 108, no 6.

Keck, M.E. y Sikkink, K. (1998). Activists beyond Borders: Advocacy Networks in International Politics. Ithaca, N.Y.: Cornell University Press.

Lafleur, J.M. (2012). “Transnacionalismo, diáspora y voto en el exterior”. En: Lafleur, J.M. (Ed.), Diáspora y voto en el exterior. Barcelona: CIDOB.

León, B.O. (2015). “El derecho de sufragio como elemento estructural de la ciudadanía europea". Revista de derecho constitucional europeo, 4.

Levitt, P. y Glick Schiller, N. (2004). "Conceptualizing Simultaneity: A Transnational Social Field Perspective on Society1.". International Migration Review, vol. 38, no. 3.

Loughlin, J. (1994). "Representing Regions in Europe: The Committee of the Regions". Regional and Federal Studies, vol. 6, no 2.

Loughlin, J. (1996). Southern Europe Studies Guide.London: Bowker-Saur. Loughlin, J. (1999). La democracia regional y local en la Unión Europea.Bruselas: Comité de las Regiones.

Ludger Pries, L. (2001). "The disruption of social and geographic space mexican-us migration and the emergence of transnational social spaces". International Sociology, vol. 16, no 1.

Máiz, R. (2004). “Per Modum Unius: más allá de la dicotomía nacionalismo cívico/nacionalismo étnico". En: Gurrutxaga, A. El Presente del Estadonación. Bilbao: UPV.

Moldes, R. (2015). “De la "integración" a la "conectividad": expectativas laborales y formas de participación de la emigración cualificada". Arxius de Ciències Socials, No. 33. 
Moraes, N. (2010). “Inclusión política, ciudadanía y territorio: algunos elementos para el debate sobre voto migrante". En: Sánchez, P. y Riella, A. (eds.), Globalización y perspectivas de la integración regional. Murcia: Universidad de Murcia.

Parlamento Europeo (2005). Informe sobre el Cuarto informe de la Comisión sobre ciudadanía de la Unión (1 de mayo de 2001 - 30 de abril de 2004), A60411/2005.

Parra, J.F. (2003). “Acercamiento al derecho de la migración y la ciudadanía transnacional. El caso de los emigrantes mexicanos y sus derechos políticos". América Latina Hoy, 33.

Portes, A. (1996). "Transnational Communities: Their Emergence and Significance in the Contemporary World System". En: Korzeniewicz, R.P. y Smith, W.C. (Eds.), Latin America in the World Economy. Westport, Conn: Greenwood Press.

Portes, A., Guarnizo, L.U. y Landolt, P. (1999) “The Study of Transnationalism: Pitfalls and Promise of an Emergent Research Field", Ethnic and Racial Studies, vol. 22, no. 2.

Smith, J., Chatfield, Ch. y Pagnucco, R. (Eds.) (1997). Transnational Social Movements and Global Politics: Solidarity beyond the State. Syracuse, N.Y.: Syracuse University Press.

Smith, M.P. y Guarnizo, L.E. (Eds.) (1998)." Transnationalism from Below". Comparative Urban and Community Research, vol. 6.

Tarrow, S. (1998). Power in Movement: Social Movements and Contentious Politics. Cambridge: Cambridge University Press.

Tortosa, J.M. (1999). “La Unión Europea: el difícil juego de tres nacionalismos”. En: Europa en la encrucijada. Zaragoza: Departamento de Educación y Cultura.

Velasco, J.C. (2009). "Transnacionalismo migratorio y ciudadanía en mutación". Claves de razón práctica, no 197.

Vertovec, S. (2003). “Transnational Migration: International Perspectives”. International Migration Review, vol. 37, no 3.

Vertovec, S. (2007). "Super-diversity and its implications". Ethnic and racial studies, vol. 30, no 6. 
ANTONIO FRANCISCO ALAMINOS CHICA es catedrático de Sociología Matemática en la Universidad de Alicante. Sus líneas de investigación son los métodos y técnicas de investigación social comparada, los procesos de socialización y aculturación y las dinámicas de cambio social y político.

CLEMENTE PENALVA VERDÚ es profesor titular en la Universidad de Alicante e investigador del Instituto Interuniversitario de Desarrollo Social y Paz. Sus principales líneas de investigación son capital social y movilización social, redes de apoyo mutuo y redes para la acción política, y la dimensión económica de la confianza social.

IGNACIA PEREA CRESPO es socióloga. Actualmente realiza el doctorado en la Universidad de Alicante donde ha colaborado en diversos proyectos de investigación con el Observatorio Europeo de Tendencias Sociales (OBETS) y el Instituto Interuniversitario de Desarrollo Social y Paz. Sus principales intereses de investigación son migraciones, multiculturalismo, aculturación y métodos de investigación social.

Recibido: $15 / 09 / 2016$

Aceptado: 28/11/2016 